\title{
Oral administration of L-arginine in patients with angina or following myocardial infarction may be protective by increasing plasma superoxide dismutase and total thiols with reduction in serum cholesterol and xanthine oxidase
}

\author{
Pratima Tripathi, ${ }^{1}$ M. Chandra ${ }^{2}$ and M.K. Misra ${ }^{1, *}$ \\ 'Department of Biochemistry; Lucknow University; Lucknow, India; ${ }^{2}$ Department of Medicine; CSM Medical University; Lucknow, India
}

Abbreviations: SOD, super oxide dismutase; SH, sulfhydryl; XO, xanthine oxidase; ROS, reactive oxygen species; SL, sarcolemmal; SR, sarcoplasmic reticulum; GPx, glutathine peroxidase; GR, glutathione reductase; EDTA, ethylene diamine tetra acetic acid; NBT, nitroblue tetrazolium; TCA, tri chloro acetic acid; DTC, dinitrophenylhydrazine, thiourea, copper sulphate; DTNB, 2,2-dithio bis nitrobenzoic acid; MDA, malondialdehyde; TBA, thiobarbituric acid; SDS, sodium dodecyl sulphate; TEP, 1,1,3,3-tetraethoxy propane; DNPH, 2,4-dinitrophenyl hydrazine; DHA, dehydro ascorbic acid; ANOVA, analysis of variance; MI, myocardial infarction; AA, acute angina; NO, nitric oxide

Key words: L-arginine, oxidative stress, myocardial injury, nitric oxide, myocardial infarction, acute angina

Administration of L-arginine has been shown to control ischemic injury by producing nitric oxide which dilates the vessels and thus maintains proper blood flow to the myocardium. In the present study attempt has been made to determine whether oral administration of L-arginine has any effect on oxidant/antioxidant homeostasis in ischemic myocardial patients [represented by the patients of acute angina (AA) and acute myocardial infarction (MI)]. L-arginine has antioxidant and antiapoptotic properties, decreases endothelin-1 expression and improves endothelial function, thereby controlling oxidative injury caused during myocardial ischemic syndrome. Effect of L-arginine administration on the status of free radical scavenging enzymes, pro-oxidant enzyme and antioxidants viz. total thiols, carbonyl content and plasma ascorbic acid levels in the patients has been evaluated. We have observed that L-arginine administration (three grams per day for 15 days) resulted in increased activity of free radical scavenging enzyme superoxide dismutase (SOD) and increase in the levels of total thiols (T-SH) and ascorbic acid with concomitant decrease in lipid per-oxidation, carbonyl content, serum cholesterol and the activity of proxidant enzyme, xanthine oxidase (XO). These findings suggest that the supplementation of L-arginine along with regular therapy may be beneficial to the patients of ischemic myocardial syndromes.

${ }^{*}$ Correspondence to: M.K. Misra; Department of Biochemistry, University of Lucknow; Lucknow 226007 India; Email: profmkmisra@sify.com

Submitted: 05/22/09; Revised: 06/07/09; Accepted: 06/08/09

Previously published online as an Oxidative Medicine and Cellular Longevity E-publication:

http://www.landesbioscience.com/journals/oximed/article/9233

\section{Introduction}

Myocardial ischemia can result from a variety of pathological and physiological disorders. Whatever the cause of ischemia, the consequence is always decreased oxygen availability to the myocardium. Insufficient oxygen supply fails to support oxidative phosphorylation. Within few minutes of ischemia, to meet the energy demand, glycolytic pathway is greatly stimulated with resultant accumulation of lactic acid resulting in acidosis. Anaerobic production of ATP in this situation is insufficient to meet the energy demand of the tissues. With continuing ischemia the tissue levels of ATP fall and this initiates a series of events, especially oxidative stress conditions, which are deleterious to the endothelial cells. Oxidative stress, associated with increased formation of reactive oxygen species (ROS), modifies phospholipids and proteins leading to lipid per-oxidation and oxidation of thiol groups. These changes are considered to alter the membrane permeability and configuration. ${ }^{1,2}$ Oxidative stress may result in cellular defects including a depression in the sarcolemmal (SL) $\mathrm{Ca}^{2+}$ pump, ATPase and $\mathrm{Na}^{+}-\mathrm{K}^{+}$ATPase activities. These changes lead to decreased $\mathrm{Ca}^{2+}$ efflux and increased $\mathrm{Ca}^{2+}$ influx ${ }^{3}$ and thus inhibit $\mathrm{Ca}^{2+}$ sequestration from the cytoplasm in the cardiomyocytes. ${ }^{4,5}$ The oxidative stress induced changes in sarcoplasmic reticulum (SR) $\mathrm{Ca}^{2+}$ and $\mathrm{SL} \mathrm{Na}{ }^{+}-\mathrm{K}^{+}$pumps are not limited only to cardiomyocytes but have also been observed in the coronary artery smooth muscle cells. ${ }^{6}$ The depression in $\mathrm{Ca}^{2+}$ regulatory mechanism by ROS ultimately results in intracellular $\mathrm{Ca}^{2+}$ overload and cell death. On the other hand, an increase in $\mathrm{Ca}^{2+}$ during ischemia induces conversion of xanthine dehydrogenase to xanthine oxidase, by selective proteolysis, that generates more of super oxide radicals. ${ }^{7}$ The super 
oxide radicals, though less toxic by itself, triggers the formation of other reactive oxygen species. These include $\mathrm{OH}, \mathrm{H}_{2} \mathrm{O}_{2}$ and $\mathrm{HOCl}^{-}$. The hydroxyl radicals, in particular, interact with lipids, proteins and nucleic acids resulting in the loss of membrane integrity, structural and functional changes in enzymes, proteins and genetic material. ${ }^{8}$ These deleterious effects result in the loss of heart contractile function and severe myocardial cell damage. To counter the damaging effects of ROS, body has evolved certain defense mechanisms to deactivate/destroy them before they can cause damage. The oxidative damage will occur only in situations when the defense mechanisms are deficient, made less active or production of ROS exceeds the capabilities of defense mechanism or a combination of all these. The first line of defense in the body are enzymatic free radical scavengers such as superoxide dismutase (SOD), catalase, glutathione peroxidase (GPx) and glutathione reductase (GR). SOD is considered to be the first line of defense against oxidative insult, as this enzyme efficiently converts oxygen derived free radical to hydrogen peroxide. Hydrogen peroxide is more toxic than oxygen derived free radicals and is capable of producing most toxic $\mathrm{OH}^{\circ}$ radical. It has, therefore, to be removed very efficiently. Catalase is the highly reactive enzyme in most of the tissues that converts toxic $\mathrm{H}_{2} \mathrm{O}_{2}$ to water. Another enzyme that removes $\mathrm{H}_{2} \mathrm{O}_{2}$ is glutathione peroxidase. This enzyme, almost equally efficient as catalase, removes $\mathrm{H}_{2} \mathrm{O}_{2}$ at the expense of oxidation of glutathione. Oxidized glutathione is reduced back by glutathione peroxidase. In fact catalase and glutathione peroxidase cooperate in removing $\mathrm{H}_{2} \mathrm{O}_{2}$ in many tissues. For example, mammalian red blood cells (RBCs) have both these enzymes. The normal low rate of production of $\mathrm{H}_{2} \mathrm{O}_{2}$ by hemoglobin and SOD seems mainly dealt with glutathione peroxidase. However, catalase also contributes to removal of $\mathrm{H}_{2} \mathrm{O}_{2}$ if it's concentration is raised. ${ }^{9}$ All these enzymes convert ROS to less toxic or non toxic products. The second line of defense to ROS is provided by antioxidant compounds present in the body such as thiols, or taken from outside such as $\alpha$-tocopherol, $\beta$-carotenoids, flavonoids and $\mathrm{L}$-arginine. We have earlier shown that administration of vitamin $\mathrm{C}^{10,11}$ and vitamin $\mathrm{E}^{12,13}$ to the patients of ischemic myocardial syndromes lower lipid per-oxidation, increase the activities of free radical scavenging enzymes, which are decreased in these patients, and lower the activity of pro-oxidant enzyme which are elevated in the patients. Oxidized low density lipo-proteins are involved in the progression of atherosclerotic lesions ${ }^{14}$ which can be prevented by L-arginine administration. Moreover there are evidences that this amino acid preserves arterial vasodilation even in the presence of oxidative stress. ${ }^{15-17}$ A fine balance between ROS and various anti-oxidant mechanisms is crucial for avoiding myocardial injury. In the present study we have tried to evaluate the effect of L-arginine administration on certain pro-oxidant and antioxidant parameters in myocardial ischemic syndromes like acute myocardial infarction and acute angina.

\section{Results}

Myocardial ischemic syndromes are almost invariably associated with alterations with oxidant and anti-oxidant parameters. Levels of SOD, an important enzymatic free radical scavenger and $\mathrm{XO}$,

\section{Table 1 Personal profile of the subjects included in the} study
1. No. of subjects
${ }^{*} \mathrm{Ml}$ (without Arg/with Arg)
$35 / 20$
*AA (without Arg/with Arg)
$25 / 20$
2. Sex
Males
3. Age
40-75 yrs

$35 / 20$
$25 / 20$
Males
$40-75$ yrs

4. Duration of cardiac disease prior to L-arginine therapy

5. Tobacco chewers

6. Smokers
Immediately after detection of the disease by the physician

None

None

None

None

15 days ( $3 \mathrm{~g} /$ day)

Indian
*No. of subjects; MI, Acute myocardial infarction; AA, Acute angina.

Table 2 Age and blood pressure of patients of acute myocardial infarction (MI) and acute angina (AA)

\begin{tabular}{lccc}
\hline Groups & $\begin{array}{c}\text { Age } \\
\text { (years) }\end{array}$ & $\begin{array}{c}\text { Blood pressure } \\
(\mathbf{m m ~ H g})\end{array}$ & $\begin{array}{c}\text { Serum cholesterol } \\
(\mathbf{m g} / \mathbf{d l})\end{array}$ \\
Group (1) & $60 \pm 10$ & $138 \pm 10 / 77 \pm 4$ & $405.00 \pm 76.70$ \\
Group (2) & $60 \pm 10$ & $115 \pm 5 / 80 \pm 9$ & $255.40 \pm 41.53$ \\
Group (3) & $55 \pm 10$ & $126 \pm 14 / 81 \pm 10$ & $354.90 \pm 71.09$ \\
Group (4) & $55 \pm 10$ & $116 \pm 5 / 77 \pm 5$ & $252.70 \pm 42.51$
\end{tabular}

Effect of L-arginine (Arg) administration on the levels of serum cholesterol in the patients of MI and AA are also reported. Serum cholesterol levels in patients was estimated by the method of Sperry and Webb. Values for cholesterol levels are presented as mean \pm SD. Statistical significance of the groups has been determined by one way ANOVA followed by Newmann-Keul's multiple comparison test. $p$ values of serum cholesterol level are Group 1 vs. Group $2 p<0.005$; Group 3 vs. Group $4 p<0.05$.

the major source of free radical generation have been selected in the present study. MDA levels has been used as marker of free radical mediated damage along with carbonyl content. Levels of some non-enzymatic anti-oxidants namely total thiols and ascorbic acid and levels of serum cholesterol have been monitored before and after administration of L-arginine.

The results are expressed as Mean \pm SD. One way analysis of variance (ANOVA) followed by Newman-Keul's multiple comparison test is applied to assess the significance of the data. A $\mathrm{p}<0.05$ is considered to be statistically significant. Personal data of the subjects included in the study are reported in Table 1. Age group, blood pressure and serum cholesterol levels of the subjects are reported in Table 2. Biochemical parameters investigated are presented in Tables 3 and 4. All the data are also represented graphically in Figures $1-7$.

SOD. The specific activity of SOD in plasma of MI patients receiving $\mathrm{L}$-arginine treatment along with regular anti-hypertensive therapy (Group 2) showed significant increase $(\mathrm{p}<0.05)$ when compared to those receiving only anti-hypertensive therapy 
Table 3 Effect of L-arginine (Arg) administration on the activities of SOD and XO and MDA levels in patients of acute myocardial infarction (MI) and acute angina (AA)

\begin{tabular}{lccc}
\hline Groups & $\begin{array}{c}\text { SOD } \\
\text { (unit/mg protein) }\end{array}$ & $\begin{array}{c}\text { XO } \\
\text { (unit/mg protein) }\end{array}$ & $\begin{array}{c}\text { MDA } \\
\text { (nmole/ml) }\end{array}$ \\
Group 1 & $1.91 \pm 0.79$ & $0.94 \pm 0.17$ & $4.61 \pm 1.27$ \\
Group 2 & $2.32 \pm 0.68$ & $0.68 \pm 0.16$ & $3.65 \pm 1.24$ \\
Group 3 & $2.80 \pm 0.71$ & $0.82 \pm 0.15$ & $1.91 \pm 0.75$ \\
Group 4 & $3.05 \pm 0.77$ & $0.65 \pm 0.14$ & $1.40 \pm 0.48$
\end{tabular}

SOD activity in patients was estimated by the method of Misra and Fridovich. Activity of XO was estimated by the method of Fried and Fried. Levels of MDA was determined by Ohkawa et al. Values are presented as mean \pm SD. Statistical significance of the groups was determined by one way ANOVA followed by Newmann-Keul's multiple comparison test. p values: Superoxide dismutase (SOD), Group 1 vs. Group $2 p<0.05$; Group 3 vs. Group $4 p>0.05$. Xanthine oxidase (XO), Group 1 vs. Group $2 p<0.005$; Group 3 vs. Group $4 p<0.05$. Malondialdehyde (MDA), Group 1 vs. Group $2 p<0.05$; Group 3 vs. Group $4 p>0.05$.

\section{Table 4 Effect of L-arginine (Arg) administration on the levels of total thiols, ascorbic acid and carbonyl content in patients of acute myocardial infarction (MI) and acute angina (AA)}

$\begin{array}{lccc}\text { Groups } & \begin{array}{c}\text { Total thiols } \\ (\mathbf{m m o l e} / \mathbf{m l})\end{array} & \begin{array}{c}\text { Ascorbate level } \\ (\mathbf{m g} / \mathrm{dl})\end{array} & \begin{array}{c}\text { Carbonyl protein } \\ \text { ( } \mathrm{mmole} / \mathbf{m l})\end{array} \\ \text { Group 1 } & 0.22 \pm 0.067 & 0.26 \pm 0.88 & 54.28 \pm 22.92 \\ \text { Group 2 } & 0.31 \pm 0.068 & 0.37 \pm 0.16 & 38.38 \pm 17.48 \\ \text { Group 3 } & 0.32 \pm 0.041 & 0.39 \pm 0.10 & 21.27 \pm 11.57 \\ \text { Group 4 } & 0.39 \pm 0.072 & 0.49 \pm 0.15 & 16.82 \pm 7.11\end{array}$

Levels of total thiols in patients were estimated by the method of Hu. Ascorbic acid level was determined by the method of Omaye et al. Carbonyl content was determined by the method of Levini et al. Values are presented as mean \pm SD. Statistical significance of the groups was determined by one way ANOVA followed by Newmann-Keul's multiple comparison test. p values: Total thiols: Group 1 vs. Group $2 p<$ 0.005 ; Group 3 vs. Group $4 p<0.05$. Ascorbic acid: Group 1 vs. Group $2 p<0.05$; Group 3 vs. Group $4 p<0.05$. Carbonyl content: Group 1 vs. Group $2 p<0.05$; Group 3 vs. Group $4 p>0.05$.

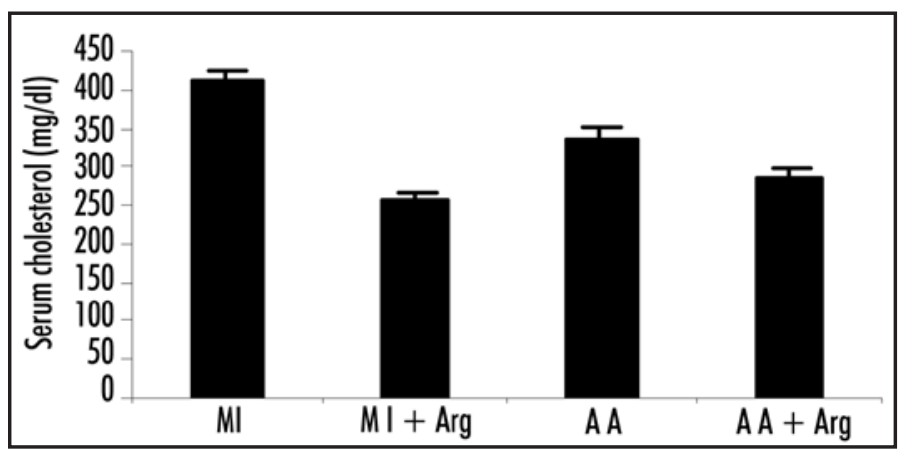

Figure 1. Effect of L-arginine (Arg) administration on the levels of Serum cholesterol in patients with acute myocardial infarction (MI) and acute angina (AA). Values are presented as mean with standard error bars. Statistical significance of the groups has been determined by one way ANOVA followed by Newmann-Keul's multiple comparison test. $p$ values of serum cholesterol levels are: Ml vs. Ml+ARG $p<0.005 ; A$ A vs. A $A+A R G p<0.05$.
(Group 1). In acute angina patients L-arginine treatment though caused an increase in SOD activity but was statistically not significant ( $\mathrm{p}>0.05$, Group 4 vs. Group 3).

$\mathrm{XO}$. Specific activity of $\mathrm{XO}$ was found to decrease significantly upon L-arginine treatment, both in the case of patients of MI and acute angina (Group 1 vs. 2 and Group 3 vs. 4; p < 0.005 and $\mathrm{p}<0.05$ respectively)

MDA. MDA levels in plasma were found to be significantly reduced $(p<0.05)$ when arginine was given in the case of MI patients (Table 2). There was decrease in the levels of MDA in the patients of acute angina also, but the decrease was statistically insignificant $(\mathrm{p}>0.05)$.

Plasma ascorbic acid level. In both the patient groups, administration of arginine resulted in statistically significant increase in the levels of plasma ascorbic acid (Group 1 vs. Group 2, p < 0.05 and Group 3 vs. 4, p < 0.05).

Total thiols. Total thiol levels also exhibited significant increase in both the cases of patients upon arginine incorporation in the therapy.

Carbonyl content in plasma protein. Incorporation of arginine in the therapy led to decrease in the levels of carbonyl content, in case of MI patients the decrease was statistically significant $(p<0.05)$ whereas in the patients of angina it was not significant $(\mathrm{p}>0.05)$.

Serum cholesterol. Incorporation of arginine was also effective in lowering the serum cholesterol levels in both groups of patients (Table 1) and this lowering was highly significant showing the $\mathrm{p}$ value of $<0.005$ in case of MI patients and $<0.05$ in the patients of angina.

\section{Discussion}

As reported in the results section, most of the oxidant-antioxidant parameters studied, showed a tendency to improve upon administration of L-arginine. Most of the xanthine oxidizing activity present in healthy animal tissues occurs as a dehydrogenase enzyme that oxidizes hypoxanthine and/or xanthine to uric acid at the expense of NAD. During ischemia, insufficient oxygen supply fails to support oxidative phosphorylation, leading to lowering of tissue ATP levels and acidosis. ATP hydrolysis eventually leads to production of hypoxanthine and xanthine. Thus there is accumulation of substrates of xanthine oxidase. ${ }^{18}$ As mentioned in the introduction section, levels of $\mathrm{Ca}^{+2}$ are also increased during ischemia. This increase in $\mathrm{Ca}^{+2}$ stimulates certain proteases that selectively act on xanthine dehydrogenase to convert it in to xanthine oxidase. ${ }^{19}$ Xanthine oxidase mediated production of OFRs plays major role in causing tissue damage observed in ischemia/reperfusion injury as evidenced by the fact that incorporation of specific inhibitors of xanthine oxidase, such as allopurinol and anti-oxidants, are capable to protect such damage in experimental models of myocardial injury. ${ }^{20-22}$ The series of events initiated by ischemia, lead to enhanced production of free radicals which is further increased upon reperfusion of ischemic myocardium. ${ }^{10,11}$

Oxy free radicals are removed by superoxide dismutase in healthy organisms, but during ischemia, the lowered activity of SOD caused by inhibition of the enzyme by excess $\mathrm{H}_{2} \mathrm{O}_{2}$ 
production fails to cope with excessive production of free radicals and $\mathrm{H}_{2} \mathrm{O}_{2}$. This excess $\mathrm{H}_{2} \mathrm{O}_{2}$, besides inhibiting SOD, can cause degradation of heme rings of hemoglobin releasing iron which is capable of $\mathrm{OH}$ production via Fenton reaction and lipid peroxidation. ${ }^{23}$ Lipid per-oxidation and free radical mediated damage during ischemia is indicated by increased MDA levels in patients suffering from myocardial infarction and acute angina in the present study. Total thiols can either chemically ${ }^{24}$ or enzymatically reduce dehydroascorbic acid (DHA) to ascorbate. ${ }^{25,26}$ The lower level of total thiols in patients may be responsible for the decreased conversion of DHA back to ascorbate. Ascorbic acid, an effective antioxidant is capable of completely protecting lipids against oxidative damage induced by peroxy radicals. It has chain breaking properties, reacts directly with superoxide ions, hydroxyl radicals and singlet oxygen species and acts to generate tocopherol. ${ }^{27}$ During ischemia the lowered levels of total thiols may be responsible for decreased conversion of DHA to ascorbate. This may be one of the reasons that we observed decreased levels of ascorbic acid in the patients. Decrease in ascorbate level fails to cope with per-oxidative damage of lipids and modification of phospholipids, thereby resulting in increased lipid per-oxidation. Decreased levels of total thiols also indicate the effect of oxidative damage of protein molecules due to excessive free radical generation during ischemia. Major parts of thiols are derived from proteins. Oxidative damage modifies proteins leading to oxidation of thiol groups. ${ }^{28}$ The modifications in lipids and proteins caused due to decreased levels of ascorbic acid and thiols in patients alter membrane permeability and configuration in addition to producing functional modification of various cellular proteins during ischemia. Excessive free radical generation during ischemia causes the inactivation of enzymes and introduction of carbonyl groups into amino acid side chains of proteins. Increased carbonyl derivatives within proteins and enzyme inactivation suggest mixed-function oxidative modification. ${ }^{29}$

During ischemia, the myocardial tissue is exposed to an exacerbated injury caused by un-scavenged superoxide radicals, other free radicals, increased WBC, vasoconstriction and platelet adhesion. ${ }^{30-32}$ Higher oxidant stress and diminished antioxidant status along with higher MDA levels constitutes the key factors in the progression of ischemic injury.

L-arginine serves as a precursor of nitric oxide $(\mathrm{NO})$ synthesis. $\mathrm{NO}$ can reduce oxidative stress by inhibiting $\mathrm{XO}$, scavenge superoxide radicals and terminate free radical chain reaction within the lipid membranes, thereby reducing inflammatory mediators. ${ }^{33,34}$ Decreased ROS formation attenuates inhibition of SOD which is increased by L-arginine supplementation. In the present study, it was found that the level of ascorbic acid and total thiols also increased after L-arginine supplementation. Our present finding is in accordance with. ${ }^{33}$ The improved levels of ascorbic acid and total thiols cope with lipid and protein per-oxidation thus decreasing the damage of membrane and cellular proteins. By efficiently reducing or eliminating these toxic metabolites L-arginine via $\mathrm{NO}$ retards the damaging effects of ischemic injury. ${ }^{34}$

$\mathrm{L}$-arginine controls the modification of proteins due to excess carbonylation and that is why in our study, L-arginine was found to significantly decrease the plasma carbonyl contents in the patients.

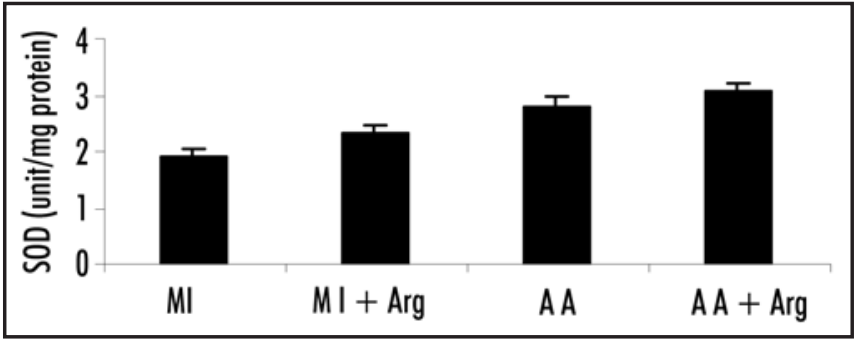

Figure 2. Effect of L-arginine (Arg) administration on superoxide dismutase (SOD) activity in patients with acute myocardial infarction (MI) and acute angina (AA). Values are presented as mean with standard error bars. Statistical significance of the groups has been determined by one way ANOVA followed by Newmann-Keul's multiple comparison test. $p$ values of SOD activity are: $M l$ vs. Ml+ARG $p<0.05 ; A$ A vs. AA +ARG $p>0.05$.

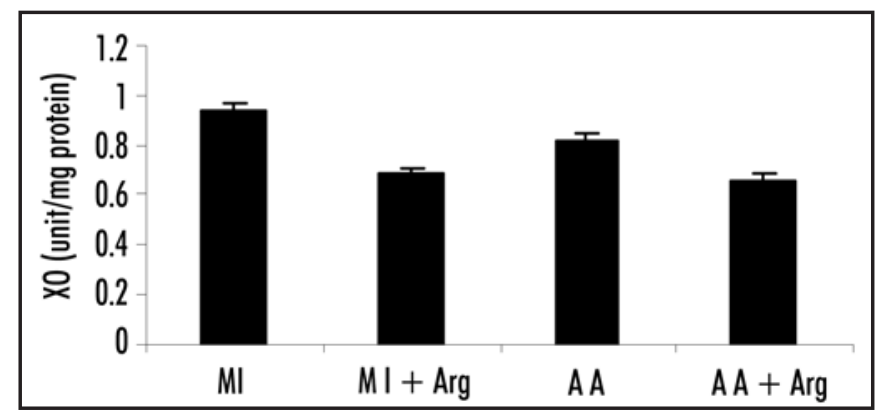

Figure 3. Effect of L-arginine (Arg) supplementation on xanthine oxidase (XO) activity in patients with acute myocardial infarction (MI) and acute angina (AA). Values are presented as mean with standard error bars. Statistical significance of the groups has been determined by one way ANOVA followed by Newmann-Keul's multiple comparison test. $p$ values of $X O$ activity are: $M I$ vs. $M I+A R G p<0.005 ; A A$ vs. $A A+A R G p<0.05$.

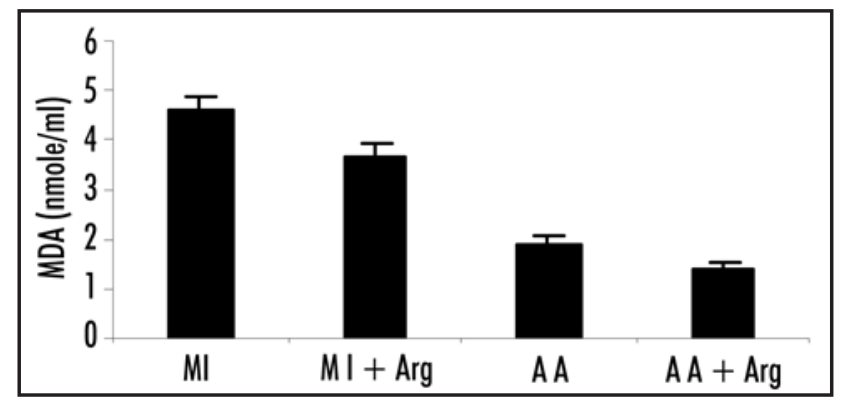

Figure 4. Effect of L-arginine (Arg) supplementation on the levels of malondialdehyde (MDA) in patients with acute myocardial infarction (MI) and acute angina (AA). Values are presented as mean with standard error bars. Statistical significance of the groups has been determined by one way ANOVA followed by Newmann-Keul's multiple comparison test. $p$ values of $M D A$ levels are: $M I$ vs. $M I+A R G p<0.05 ; A A$ vs. $A A+A R G$ $p>0.05$.

$\mathrm{NO}$ generated by L-arginine also inhibits vasoconstriction, platelet aggregation, expression of adhesion molecules, ${ }^{35}$ and chemotactic proteins. ${ }^{36}$ Another interesting finding of the present work is that L-arginine administration to the patients has serum cholesterol lowering effect, an observation reported by few earlier workers. ${ }^{37,38}$ 


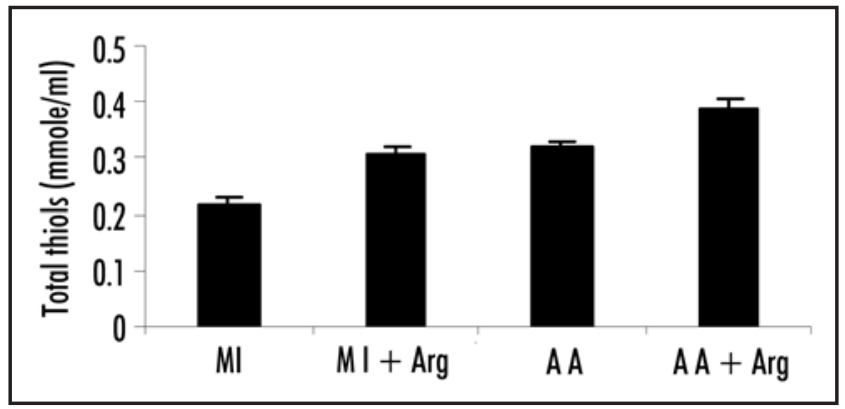

Figure 5. Effect of L-arginine (Arg) supplementation on the levels of total thiols in patients with acute myocardial infarction (MI) and acute angina (AA). Values are presented as mean with standard error bars. Statistical significance of the groups has been determined by one way ANOVA followed by Newmann-Keul's multiple comparison test. $p$ values of total thiols levels are: $M I$ vs. $M I+A R G ~ p<0.005 ; A A$ vs. $A A+A R G p<0.05$.

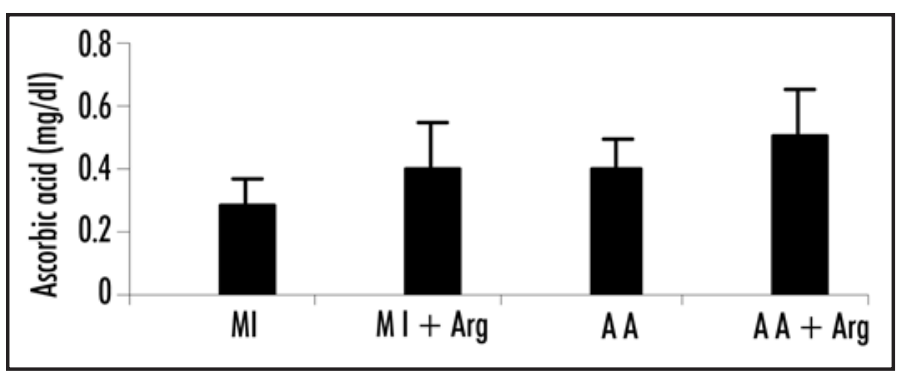

Figure 6. Effect of L-arginine (Arg) supplementation on the levels of ascorbic acid in patients with acute myocardial infarction (MI) and acute angina (AA). Values are presented as mean with standard error bars. Statistical significance of the groups has been determined by one way ANOVA followed by Newmann-Keul's multiple comparison test. $p$ values of ascorbic acid levels are: $M I$ vs. MI+ARG $p<0.05 ; A A$ vs. AA+ARG $p<0.05$.

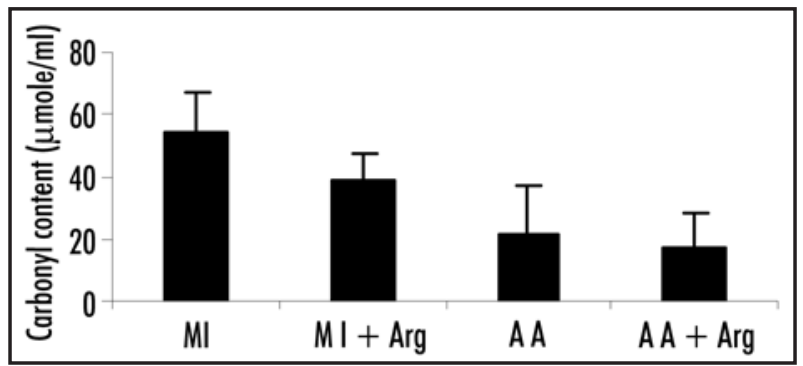

Figure 7. Effect of L-arginine (Arg) supplementation on the levels of carbonyl content in patients with acute myocardial infarction (MI) and acute angina (AA). Values are presented as means with standard error bars. Statistical significance of the groups has been determined by one way ANOVA followed by Newmann-Keul's multiple comparison test. $p$ values of carbonyl content are: $M I$ vs. Ml+ARG $p<0.05$; $A A$ vs. $A A+A R G$ $p>0.05$.

The observed lowering of serum cholesterol upon L-arginine administration, has been ascribed to be mediated by NO derived from this amino acid. ${ }^{39}$ The adhesiveness of mononuclear cells is increased in hyper-cholesterolemic conditions. The increase in adhesiveness and cholesterol levels lead to atherosclerosis and myocardial infarction and can be taken care of by L-arginine

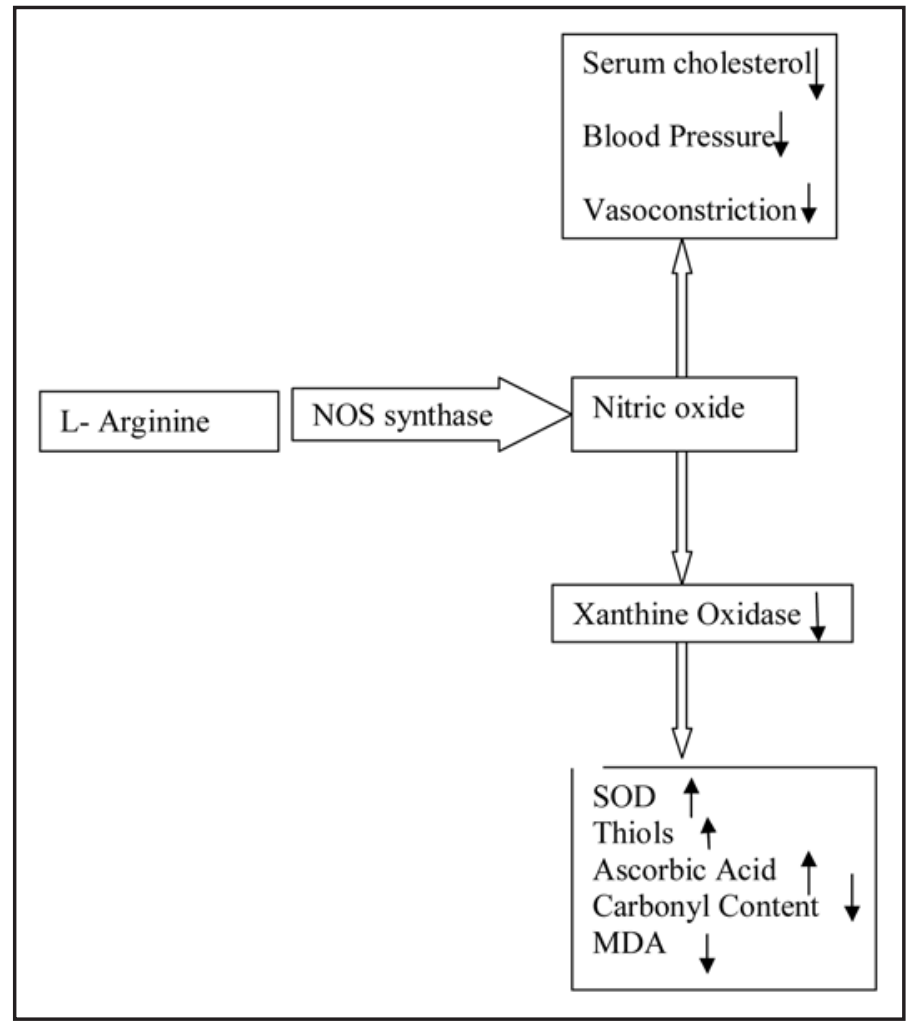

Figure 8. Mechanism of action of L-arginine on the parameters examined in the present study. The action of L-arginine is shown to be mediated by nitric oxide (NO), which in turn, lowers $(\downarrow)$ the serum cholesterol level in patients, controls vasoconstriction and thus regulates their blood pressure. Also, NO attenuates the activity of $\mathrm{XO}(\downarrow)$ due to which the activity of SOD is elevated ( $\uparrow$ ). L-arginine is also shown to increase the levels of thiols and ascorbic acid $(\uparrow)$ and reduce MDA levels and carbonyl content in plasma $(\downarrow)$.

supplementation to these patients. Possible pathway presenting the action of L-arginine on the parameters examined in the present study is provided in Figure 8.

L-arginine supplementation, along with standard therapy in the patients under present study, can maintain oxidant-antioxidant homeostasis and control the levels of lipid, cholesterol, ascorbic acid and protein oxidation in patients of myocardial ischemic syndromes.

\section{Material and Methods}

The study was cleared by the departmental ethical committee. Informed consent was obtained from individuals enrolled in the study. The study included 60 patients of the age group between 40-75 suffering from myocardial infarction and acute angina.

The patients suffering from non segment elevation myocardial infarction before reperfusion were included in MI group of the study. These patients were receiving regular antihypertensive medication.

Patients with chest pain at rest and/or on effort, positive exercise tests (chest pain associated with ST-segment depression of $>0.1 \mathrm{mV}$ ) normal coronary arteriograms and no spasm of large epicardial arteries provoked by acetylcholine were included in 
acute angina group. All these patients exhibited evidence suggestive of myocardial ischemia. None of these patients had any ST-segment abnormalities in their resting ECG's. The patients were receiving anti anginal medication.

Patients with previous cardiovascular or other organic diseases and those with severe trauma or surgery in preceding eight weeks were excluded from the study.

The patients were grouped in the following way:

Group (1): included $35 \mathrm{MI}$ patients receiving regular therapy without $\mathrm{L}$-arginine administration.

Group (2): included $20 \mathrm{MI}$ patients assigned to regular therapy along with supplementation of oral dose of L-arginine $(3 \mathrm{~g} /$ day $)$ for 15 days.

Group (3): included 25 patients of acute angina receiving regular therapy without L-arginine supplementation.

Group (4): comprised of 20 patients of acute angina with conventional therapy along with supplementation of L-arginine (3 g/day) for 15 days.

Regular treatments for both the groups (MI and acute angina) included antihypertensive drugs like nitroglycerine, monotrate, metaprolal, aspirin and clopivas.

All the chemicals employed in the study were AnalaR grade of Qualigens, biochemicals employed were procured from Sigma Chemical Co., US.

Preparation of sample. Venous blood $(4.0 \mathrm{ml})$ was drawn aseptically from the subjects under study and transferred in polypropylene tubes containing $0.5 \mathrm{ml} \mathrm{3.8 \% (w/v)} \mathrm{sodium} \mathrm{citrate,}$ $\mathrm{pH}$ 7.2. The tubes were gently rotated to mix the contents and centrifuged at $2,000 \mathrm{xg}$ for $20 \mathrm{~min}$ at $4^{\circ} \mathrm{C}$. The supernatant plasma was used for study.

Estimation of SOD. SOD was assayed in plasma by the method of Misra and Fridovich. ${ }^{40}$ Three $\mathrm{ml}$ reaction mixture consisted of $1.5 \mathrm{ml}$ of $100 \mathrm{mM}$ carbonate buffer, $\mathrm{pH}$ 10.3; $0.01 \mathrm{ml}$ of $30 \mathrm{mM}$ EDTA (ethylene diamine tetra acetic acid), suitable aliquot of enzyme preparation and water to make up the volume to $2.94 \mathrm{ml}$. The reaction was started by addition of $0.06 \mathrm{ml}$ of $15 \mathrm{mM}$ epinephrine. Change in absorbance was recorded at $480 \mathrm{~nm}$ for one min at $15 \mathrm{sec}$ interval. Control consisting of all the ingredients, except enzyme preparation, was run simultaneously.

One unit of enzyme activity has been defined to cause $50 \%$ inhibition of auto-oxidation of epinephrine present in the assay system by $1 \mathrm{ml}$ enzyme preparation.

Estimation of XO. XO (Xanthine oxidase) was assayed in plasma by the method of Fried and Fried. ${ }^{41}$ The reaction mixture consisted of $0.9 \mathrm{ml}$ of $0.1 \mathrm{M}$ phosphate buffer $\mathrm{pH} 7.8 ; 0.75 \mathrm{ml}$ $10 \mathrm{mM}$ EDTA; $0.15 \mathrm{ml} 0.2 \mathrm{mg} / \mathrm{ml}$ phenazine methosulphate; $0.45 \mathrm{ml} 4 \mathrm{mg} / \mathrm{ml}$ nitroblue tetrazolium (NBT) salt; $0.5 \mathrm{ml} 1 \mathrm{mM}$ xanthine and water to make up the volume to $3.5 \mathrm{ml}$. The reaction was started at $37^{\circ} \mathrm{C}$ by addition of $0.5 \mathrm{ml}$ of $1 \mathrm{mM}$ Xanthine for $1 \mathrm{~min}$. Extinction coefficient of the reduced NBT at $540 \mathrm{~nm}$ is $7.2 \mathrm{~cm} / \mu$ mole.

One unit of enzyme activity has been defined as amount of enzyme that converts $1 \mu$ mole of xanthine to uric acid in one minute at specified conditions of assay.
Estimation of ascorbic acid. Ascorbate level was estimated in the plasma by the method of Omaye, Turnbull and Sauberlich. ${ }^{42}$ In the assay, $1.0 \mathrm{ml}$ of plasma was precipitated with $1.0 \mathrm{ml}$ of $10 \%$ (w/v) TCA (trichloro acetic acid). To $0.5 \mathrm{ml}$ of the supernatant $0.2 \mathrm{ml}$ of DTC reagent $(3.0 \mathrm{~g}$ dinitrophenylhydrazine, $0.4 \mathrm{~g}$ thiourea and $0.05 \mathrm{~g} \mathrm{CuSO}_{4} .5 \mathrm{H}_{2} \mathrm{O}$ in $100 \mathrm{ml} 9 \mathrm{~N} \mathrm{H}_{2} \mathrm{SO}_{4}$ ) was added and the mixture was incubated at $37^{\circ} \mathrm{C}$ for $3 \mathrm{~h} .1 .5 \mathrm{ml}$ of $65 \%$ $\mathrm{H}_{2} \mathrm{SO}_{4}$ was then added to the reaction mixture and kept at room temperature for $30 \mathrm{~min}$. Absorbance was measured at $520 \mathrm{~nm}$. $\mathrm{L}$-ascorbic acid in 5\% TCA was used as reference.

Estimation of total thiols. Total thiols (T-SH) were estimated by the method of $\mathrm{Hu}^{43}$ using Ellman's reagent. In final volume of $4.0 \mathrm{ml}$, was added $0.2 \mathrm{ml}$ plasma and $0.6 \mathrm{ml}$ of $20 \mathrm{mM}$ tris- $\mathrm{HCl}$ buffer $\mathrm{pH}$ 8.2, followed by addition of $0.04 \mathrm{ml}$ of 10 $\mathrm{mM} 5,5^{\prime}$-dithionitrobis 2-nitrobenzoic acid (DTNB) in absolute methanol and $3.16 \mathrm{ml}$ of absolute methanol. The tubes were capped and color was developed for $15 \mathrm{~min}$ at room temperature. The tubes were then centrifuged at 3,000 $\mathrm{xg}$ for $20 \mathrm{~min}$. Supernatant was collected and absorbance measured at $412 \mathrm{~nm}$.

Estimation of MDA. Levels of malondialdehyde (MDA) were measured as an index of oxidative stress by the method of Ohkawa, Ohishi and Yagi, ${ }^{44}$ using thiobarbituric acid (TBA) reagent. To $0.2 \mathrm{ml}$ plasma, in a Folin tube, was added $0.2 \mathrm{ml}, 8.1 \%(\mathrm{w} / \mathrm{v})$, sodium dodecylsulphate (SDS); $1.5 \mathrm{ml}, 20 \%(\mathrm{v} / \mathrm{v})$ acetic acid and $1.1 \mathrm{ml}$ of $0.8 \%(\mathrm{w} / \mathrm{v})$ thiobarbituric acid to make up the volume to $3 \mathrm{ml}$. The tubes were heated in a water bath at $95^{\circ} \mathrm{C}$ for $1 \mathrm{~h}$ and cooled immediately under running tap water. To each tube, $1.0 \mathrm{ml}$ water and $5.0 \mathrm{ml}$ solution of butanol and pyridine $(15: 1 \mathrm{v} / \mathrm{v})$ were added, vortexed and centrifuged at $800 \mathrm{xg}$ for $20 \mathrm{~min}$. The upper layer was aspirated out and color intensity measured at $532 \mathrm{~nm}$. 1,1,3.3-tetra ethoxy propane (TEP) was used as the reference.

Estimation of carbonyl content of plasma protein. Protein oxidation was determined by protein carbonyl content in plasma by a modified method of Levini et al. ${ }^{45}$ From $0.5 \mathrm{ml}$ of plasma, proteins were precipitated using $0.25 \mathrm{ml}$ of $10 \%$ TCA. $0.75 \mathrm{ml}$ of $10 \mathrm{mM}$ DNPH (2,4-dinitrophenylhydrazine) in $2 \mathrm{M} \mathrm{HCl}$ was added to the precipitate and incubated at room temp for $30 \mathrm{~min}$. The reaction mixture was re-centrifuged using the same amount of TCA as before. The precipitate, thus obtained, was washed twice with $1 \mathrm{ml}$ ethanol/ethyl acetate $(1: 1 \mathrm{v} / \mathrm{v})$ mixture. The precipitate was dissolved in $0.75 \mathrm{ml}$ protein dissolving solution $(2 \mathrm{~g}$ SDS

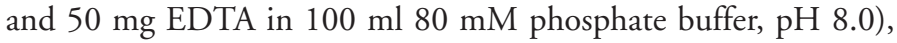
incubated for $10 \mathrm{~min}$ at room temp. The color intensity was measured at $370 \mathrm{~nm}$ against $2 \mathrm{M} \mathrm{HCl}$. Carbonyl content was calculated using the molar extinction coefficient $22,000 \mathrm{M}^{-1} \mathrm{~cm}^{-1}$.

Estimation of serum cholesterol. Serum cholesterol was determined by the method of Sperry and Webb. ${ }^{46}$ To $0.04 \mathrm{ml}$ serum, $0.96 \mathrm{ml}$ water was added to make up the volume to $1.0 \mathrm{ml}$. To this $4.0 \mathrm{ml}$ of color reagent $\left(0.1 \mathrm{ml}\right.$ of $10.0 \mathrm{~g} \mathrm{FeCl}_{3} \cdot 6 \mathrm{H}_{2} \mathrm{O}$ pet $100 \mathrm{ml}$

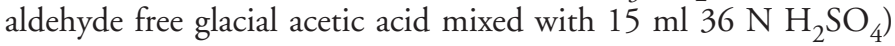
and $6.0 \mathrm{ml}$ acetic acid was added. The mixture was allowed to stand for $20 \mathrm{~min}$. The color intensity was measured at $570 \mathrm{~nm}$.

Protein estimation. Protein estimation has been carried out by the method of Lowry et al. using Folin phenol reagent. ${ }^{47}$ Bovine serum albumin was used as standard. 


\section{Effect of L-arginine in certain ischemic myocardial disorders}

Specific activity of the enzymes has been defined as unit/mg protein.

\section{Acknowledgements}

P.T. is thankful to U.P. CST for a fellowship. Grants from DST under the FIST program to the Department of Biochemistry are gratefully acknowledged.

\section{References}

1. Cerconi C, Cargnoni A, Pasini E, Condorelli E, Curello S, Ferrari R. Evaluation of phospolipid peroxidation as malondialdehyde during myocardial ischemia and reperfusion injury. Am J Physiol 1991; 260:1057-61.

2. Dhalla NS, Panagia V, Singal PK, Makino N, Dixon IM, Eyolfson DA. Alterations in heart membrane calcium transport during the development of ischemia-reperfusion injury. J Mol Cell Cardiol 1988; 20:3-13.

3. Suzuki S, Kaneko M, Chapman DC, Dhalla NS. Alterations in cardiac contractile proteins due to oxygen free radicals. Biochim Biophys Acta 1997; 1074:95-100.

4. Netticadan T, Temsah R, Osada M, Dhalla NS. Status of $\mathrm{Ca}^{2+} /$ calmodulin protein kinase phosphorylation of cardiac SR proteins in ischemia-reperfusion. Am J Physiol 1999; 277:384-91.

5. Smart SC, Sagar KB, el Schultz J, Warlteir DC, Jones LR. Injury to the $\mathrm{Ca}^{2+}$ ATPase of the Sarcoplasmic reticulum in anesthesized dogs contributes to myocardial reperfusion injury. Cardiovasc Res 1997; 36:174-84.

6. Elmoselhi AB, Butcher A, Samson SE, Grover AK. Free radicals uncouple the sodium pump in pig coronary artery. Am J Physiol 1994; 266:720-8.

7. Goldhaber JI, Weiss JN. Oxygen free radicals and cardiac reperfusion abnormalities. Hyperten 1992; 20:118-27.

8. Gilham B, Papachristodoulou DK, Thomas JH. Will's biochemical basis of medicine. Butterworth-Heinemann (ed.) 1997; 3:343-54.

9. Gaetani GF, Kirkman HN, Mangerini R, Ferraris AM. Importance of catalase in the disposal of $\mathrm{H}_{2} \mathrm{O}_{2}$ within human erythrocytes. Blood 1995; 84:325-30.

10. Bhakuni P, Chandra M, Misra MK. Oxidative stress parameters in erythrocytes of post reperfused patients with myocardial infarction. J Enz Inhibt Med Chem 2005; 20:377-81.

11. Bhakuni P, Chandra M, Misra MK. Effect of ascorbic acid supplementation on certain oxidative stress parameters in the post-reperfusion patients of myocardial infarction. Mol Cell Biochem 2006; 290:153-8.

12. Dwivedi VK, Chandra M, Misra PC, Misra MK. Effect of vitamin E on platelet enzymatic anti-oxidants in the patients of myocardial infarction. Ind J Clin Biochem 2005; 20:21-5.

13. Raghuvanshi R, Chandra M, Misra PC, Misra MK. Effect of vitamin E on the platelet xanthine oxidase and lipid per-oxidation in the patients of myocardial infarction. Ind J Clin Biochem 2005; 20:26-9.

14. Diaz MN, Frei B, Vita JA, Keaney JF. Anti-oxidants and atherosclerotic heart disease. N Engl J Med 1997; 337:408-16.

15. Wu G, Meininger CJ. Arginine nutrition and cardiovascular function. J Nutr 2006; 130:2626-9.

16. Bogle RG, Coade SB, Moncada S, Pearson JD, Mann GE. Bradykinin and ATP stimulate L-arginine uptake and nitric oxide release in vascular endothelial cells. Biochem Biophys Res Commun 1991; 180:926-32.

17. Brown AA, Hu FB. Dietary modulation of endothelial function: Implication for cardio vascular disease. Am J Ciln Nutr 2001; 73:673-86.

18. Kehrer JP, Piper HM, Sies H. Xanthine oxidase is not responsible for reoxygenation injury in isolated-perfused rat heart. Free Rad Res Commun 1987; 3:69-78.

19. Bolli R. Oxygen derived free radicals and myocardial reperfusion injury. An over view. Cardiovasc Drug Ther 1991; 5:249-68.

20. Otani H, Engelman RM, Rousou JA, Breyer RH, Lemeshow S, Das DK. Cardiac performance during reperfusion improved by pretreatment with oxygen free radical scavengers. J Thorac Cardiovasc Surg 1986; 91:290-5.

21. Fox KAA. Myocardial protection: the pathophysiology of reperfusion and reperfusion injury. In Reperfusion injury. A clinical perspective. Yellon DM, Jennings RB, (eds.,) Raven Press, New York 1992; 151-65.

22. De Lorgeril M, Richard MJ, Arnaud J, Boissonnat P, Guidollet J, Durcau G, et al. Lipid peroxides and anti-oxidant defenses in the accelerated transplantation associated coronary arteriosclerosis. Am Heart J 1993; 125:974-80.

23. Gutteridge JMC. Iron promotes Fenton reaction and lipid per oxidation can be released from hemoglobin by peroxides. FEBS Lett 1986; 201:291-5.

24. Winkler BS. In vitro oxidation of ascorbic acid and its prevention by GSH. Biochim Biophys Acta 1987; 925:258-64.

25. Basu S, Som S, Deb S, Mukherjee D, Chatterjee IB. Dehydroascorbic acid reduction in human erythrocytes. Biochim Biophys Res Commun 1979; 90:1335-40.
26. Wells WW, Xu DP, Yang YF, Rocque PA. Mammalian thioltransferase (glutaredoxin) and protein disulphide isomerase have dehydroascorbic reductase activity. J Biol Chem 1990; 265:15361-4.

27. Barton D. Prevention of atherosclerosis with dietary antioxidants: Fact or Fiction? Symposium: Formation, metabolism and physiological effects of oxidatively modified low density lipo-protein. J Nutr 1996; 126:1067-71.

28. Dhalla NS, Elmoselhi AB, Hata T, Makino N. Status of myocardial antioxidants in Ischemic-reperfusion injury. Cardiovasc Res 2000; 47:446-56.

29. Anke-G Lenz, Ulrich C, Shmuel S, Levine RL. Determination of carbonyl groups in oxidatively modified proteins by reduction with titrated Sodium Borohydride. Anal Biochem 1989; 177:419-25.

30. Buckberg GD. Studies of hypoxemic/reoxygenation injury. Linkage between cardiac function and oxidant damage. J Thorac Cardiovasc Surg 1995; 110:1164-70.

31. Ihnken K, Morita K, Buckberg GD, Sherman MP, Allen BS. Studies of hypoxemic reoxygenation injury without aortic clamping II. Evidence for reoxygenation damage. J Thorac Cardiovasc Surg 1995; 110:1171-81.

32. Mizuno A, Baretti R, Buckberg GD, Young H, Vinten-Johansen J, Ma X. Endothelia stunning and myocyte recovery after reperfusion of jeopardized muscle: a role of L-arginine blood cardioplegia. J Thorac Cardiovasc Surg 1997; 113:379-89.

33. Wan-Teng Lin, Suh-Ching Yang, Shiow-Chwen Tsai, Chi-Chang Huang, Ning-Yuean Lee. L-arginine attenuates xanthine oxidase and myeloperoxidase activities in hearts of rats during exhaustive exercise. Brit Jour Nutr 2006; 95:67-75.

34. Engelman DT, Watanabe M, Maulik N, Cordis GA, Engelman RM, Rousou JA, et al. L-arginine reduces endothelial inflammation and myocardial stunning during ischemia/ reperfusion. Ann Thorac Surg 1995; 60:1275-81.

35. Theilmeier G, Chan JR, Zalpour S, Anderson B, Wang B. Adhesiveness of Mononuclear Cells in Hypercholesterolemic Humans is normalized by Dietary L-Arginine. Arteriosclero Thromb Vasc Biol 1997; 17:3557-64.

36. Tousoulis D, Boger RH, Antoniades C, Siasos G, Stefanadi E, Stefanadis C. Mechanisms of disease: L-arginine in coronary atherosclerosis-a clinical perspective. Nat Clin Pract Cardiovas Med 2007; 4:274-83.

37. Rossitch E Jr, Alexander E, Black P, Cooke JP. L-arginine normalizes endothelial function in cerebral vessels from hypercholesterolemic rabbits. J Clin Invest 1991; 87:1295-9.

38. Hurson M, Regan MC, Kirk SJ, Wasserkrug HL. Barbul A.1 Metabolic Effects of Arginine in a Healthy Elderly Population. J Parent Enter Nutr 1995; 19:227-30.

39. Korbut R, Bieron K, Gryglewski RJ. Effect of L-arginine on plasminogen-activator inhibitor in hypertensive patients with hypercholesterolemia. The New Engl J Med $1993 ; 328: 287-8$.

40. Misra HP, Fridovich I. The role of superoxide anion in the auto-oxidation of epinephrine and a simple assay of superoxide dismutase. J Biol Chem 1972; 247:3170-5.

41. Fried R, Fried LW. Xanthine Oxidase (Xanthine Dehydrogenase) Methods. Enzymat Analys 1945; 2:644-9.

42. Omaye ST, Turnbull JD, Sauberlich HE. Selected methods for determination of ascorbic acid in animal cells, tissues and fluids. Methods Enzymol 1979; 62:3-11.

43. $\mathrm{Hu}$ M. Measurement of protein thiol groups and glutathione in plasma. Methods Enzymol 1994; 233:380-2.

44. Ohkawa H, Oshishi N, Yagi K. Assay of lipid peroxidation in animal tissues by thiobarbituric acid reaction. Anal Biochem 1979; 95:351-8.

45. Levini RL, Garland D, Oliver CN, Amici A, Climent I, Lenz A. Determination of carbonyl content in oxidatively modified proteins. Methods Enzymol 1990; 186:464-78.

46. Sperry WM, Webb M. A revision of Schoenheimer-Sperry method for cholesterol determination. J Biol Chem 1950; 187:97-106.

47. Lowry OH, Rosebrough NJ, Farr AL, Randall RG. Protein measurement with folin phenol reagent. J Biol Chem 1951; 193:265-75. 


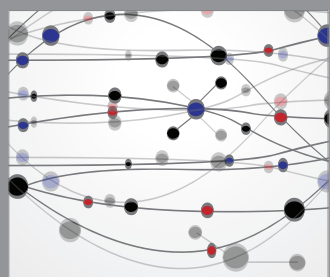

The Scientific World Journal
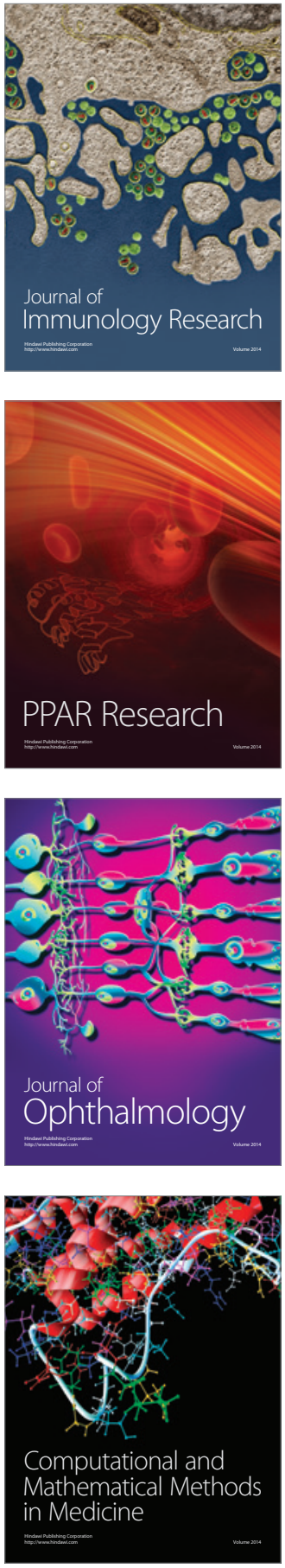

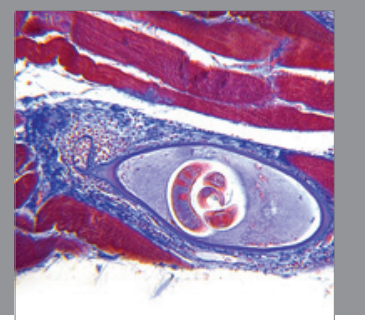

Gastroenterology

Research and Practice
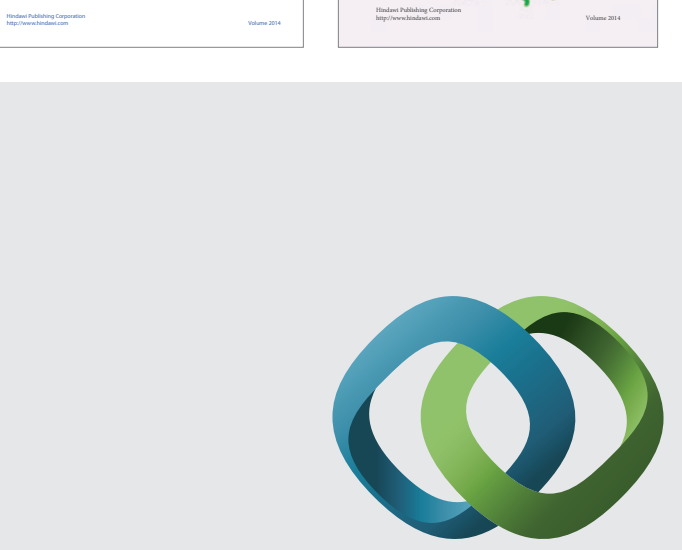

\section{Hindawi}

Submit your manuscripts at

http://www.hindawi.com
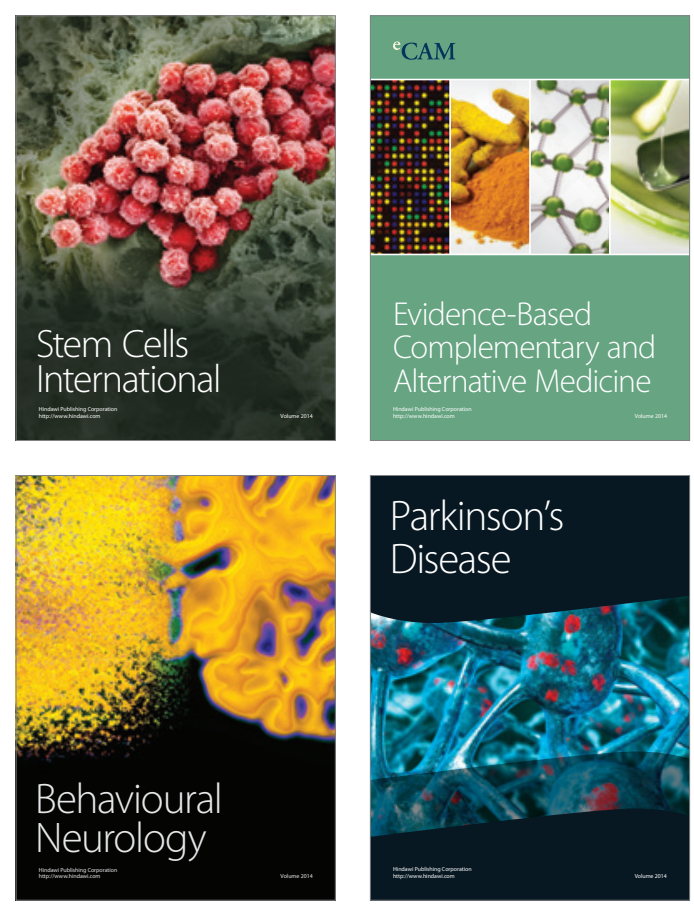

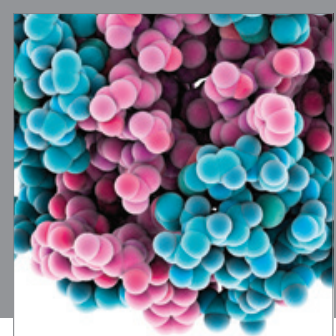

Journal of
Diabetes Research

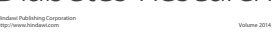

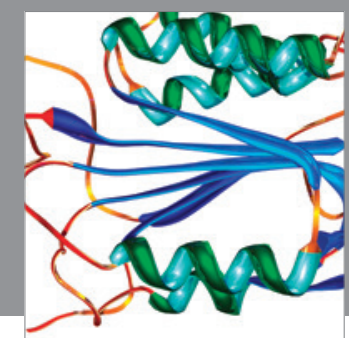

Disease Markers
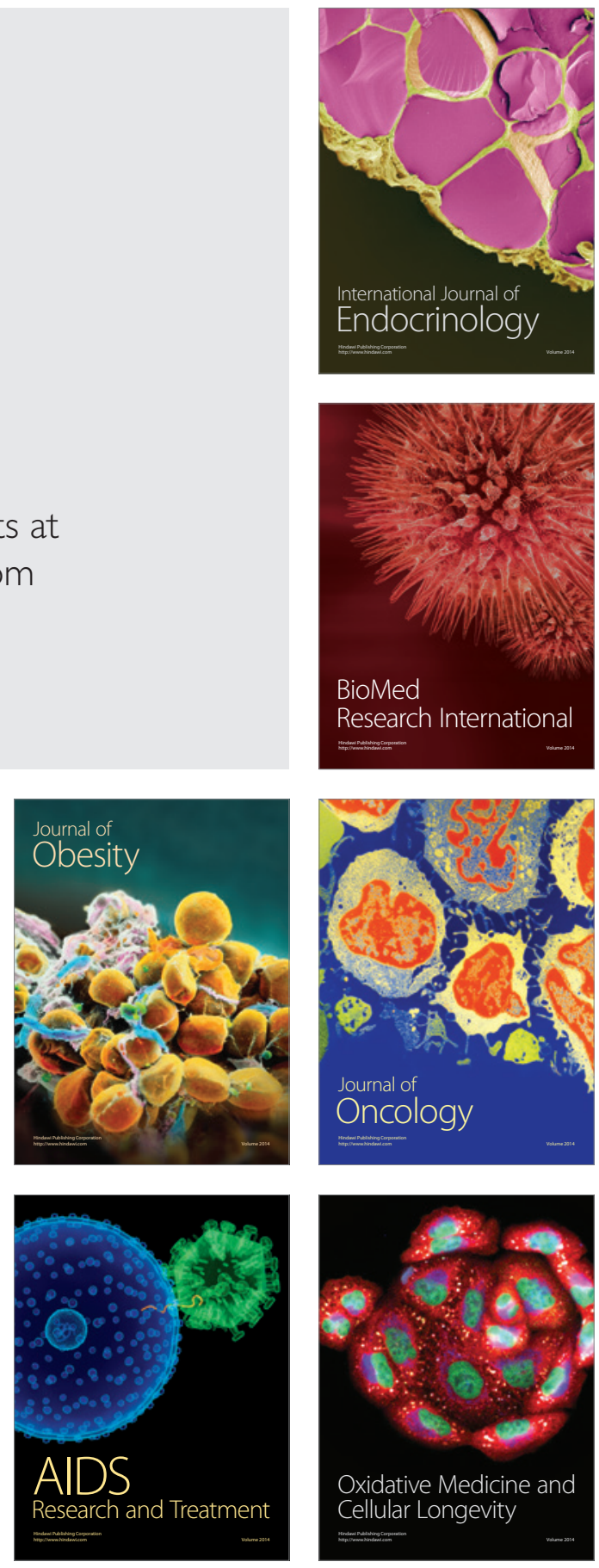